\title{
Изучение сортов льна (Linum Usitatissimum L.) в условиях Тюменской области
}

Королев К.П.*, к.с.-х.н., н.с.; Боме Н.А., д.с.-х.н., зав. кафедрой; Аксенов С.А., студент.

ФГАУ ВО Тюменский государственный университет, г. Тюмень, Россия, *e-mail: corolev.konstantin2016@yandex.ru

В условиях Тюменской области с контрастными почвенно-климатическими условиями подбор сортов льна-долгунца и льна масличного для конкретных агроэкологических зон является актуальной задачей. Впервые выявлены ответные реакиии сортов льна на изменчивость факторов среды. $B$ результате полевого испытания (2017-2019 г2.) нами установлены источники полевой всхожести семян, высоты растений, биологической устойчивости.

Ключевые слова: лен-долгунеи, лен масличный, стабильность, пластичность, полевая всхожесть, высота растений, биологическая устойчивость растений.

\section{Study of flax varieties (Linum Usitatissimum L.) in the Tyumen region}

Korolev K. P., candidate of agricultural sciences, researcher, Bome N. A., doctor of agricultural sciences, head of the Department, Aksenov S. A., student. Tyumen State University, Tyumen, Russia.

*e-mail: corolev.konstantin2016@yandex.ru

In the conditions of the Tyumen region with contrasting soil and climate conditions, the selection of varieties of fiber flax and linseeds for specific agroecological zones is an urgent task. For the first time, responses of flax varieties to the variability of environmental factors were revealed. As a result of the field test (2017-2019), we established the sources of field germination of seeds, plant height, and biological stability.

Key words: fiber flax, linseeds, stability, plasticity, field germination, plant height, biological stability of plants.

В связи с глобальными изменениями климата, все большее внимание отечественных и зарубежных исследователей отводится проблеме экологической устойчивости растений. Лен является культурой важного народнохозяйственного значения, биологический потенциал которого максимально реализуется в оптимальных условиях выращивания. Для условий Сибири сорта должны обладать высокой продуктивностью, качеством, при низком уровне зависимости от факторов среды. В Тюменской области в настоящее время культура льна не имеет широкого распространения, однако наиболее 
развито льноводство было в 70-80 гг. ХX вв. Отсутствие районированныХ сортов, адаптированной технологии выращивания, оказывает негативное влияние на практику возделывания льна, в связи с этим, подбор сортов и последующее расширение посевов льна является актуальным направлением в науке и сельскохозяйственном производстве.

Полевое испытание сортов льна проводили в 2017-2019 гг. на опытном полигоне изучения генетических ресурсов культурных растений биостанции «Озеро Кучак» Института биологии Тюменского государственного университета (Нижнетавдинский район Тюменской области). Объект исследований: сорта льна-долгунца (60 шт.) и льна масличного (40 шт.) различного эколого-географического происхождения. Закладку питомника изучения льна, фенологические учеты и наблюдения проводили в соответствии с

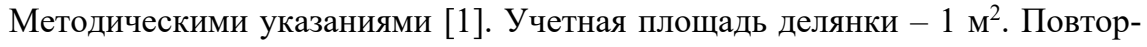
ность опытов трехкратная. Экологическую стабильность и пластичность сортов льна рассчитывали по методу S.A. Eberhart, W.W. Russell [2]. Статистическую обработку данных выполняли по методике, изложенной Б.А. Доспеховым [3]. Достоверность различий сортов и среднего популяционного значения устанавливали согласно критерию Стьюдента при 95\% уровне значимости. Цель исследования - выявить изменчивость сортов льна по полевой всхожести семян, высоте растения, биологической устойчивости при действии факторов среды.

В результате проведенных полевых исследований (2017-2019 гг.) нами выявлены различия сортов по количественным признакам (Рисунок). Установлено, что полевая всхожесть семян большинства из изученных сортов льна-долгунца характеризовалась показателями на 10,0-15,0 \% выше сортов льна масличного. Среднее популяционное значение по годам исследований составило 60,2 \% (лен-долгунец), 50,4 \% (лен масличный). Достоверные различия установлены у сортов льна-долгунца: Томский-16 (72,1 \%), TOCT (72,3 \%), Рубин (71,5 \%), Печерский кряж (71,1 \%), Велижский кряж (70,3 \%), Дукат (70,1 \%), Восход (70,0 \%), Upite-2 (69,2 \%), Honkei 41 $(69,1 \%)$, Маяк (69,9 \%); льна масличного: Северный $(61,9 \%)$, Бирюза $(60,8 \%)$, Исилькульский $(60,7 \%)$, Кустанайский янтарь $(60,0 \%)$, Antares $(59,9 \%)$, Сокол $(59,1 \%)$.

Учитывая, что у льна-долгунца, стебель - хозяйственно-ценная часть растения, выявление источников высокорослости, является одним из основных составляющих при оценке исходного материала. Нами установлены фенотипические различия между сортами по высоте растений, как по годам, так и по сортам. Минимальную высоту растений льна - долгунца выявили в условиях 2019 г. (70,0 см, Hermes; Велижский кряж, 72,0 см), максимальную (Ива, 105,1 см; 104,5 см, Грант) в 2017 г. У льна масличного минимальное значение высоты (39,0 см, Кустанайский янтарь, Ручеек, 38,9 см, Krocus, 37,2 см) в 2018 г.; максимальное проявление признака (Артем, 77,0 см, ВМ- 
620, 75,1 см; Нилин, 74,0 см) зарегистрировали в 2019 г. Среднее популяционное значение составило для генотипов льна-долгунца (92,9 см), льна масличного $(65,0$ см).
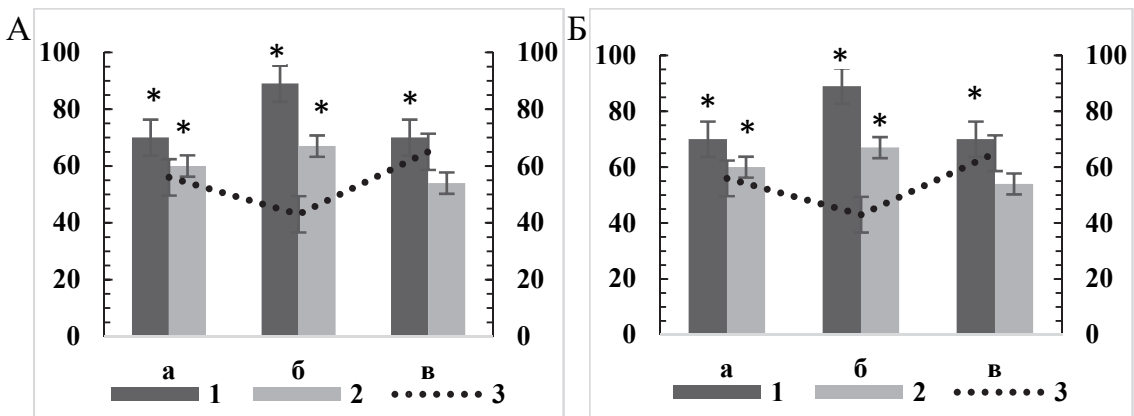

Примечание: * - различия со средним популяционным значением статистически достоверны при $\mathrm{P}<0,05$. Признаки: полевая всхожесть семян, \% (a); высота растения, см (б); биологическая устойчивость растений, \% (в). Лимиты: $\max (1), \min (2)$. Среднее арифметическое (3). По левой оси: среднее арифметическое по лимитам; по правой оси: среднее популяционное значение.

Рисунок. Количественные признаки у сортов льна-долгунца (А) и льна масличного (Б) в условиях полевого опыта (2017-2019 гг.).

В качестве источников высокорослости льна-долгунца, рекомендуем сорта: Alizee (103,8 см), Ива (103,2 см), Глинум (101,4), Дукат (100,5 см), Рубин (99,4 см); Ярок (98,7 см), Восход (97,3 см), Upite-2 (97,2 см).

Биологическая устойчивость растений определяется генотипическими особенностями генотипов, степенью их адаптивности. При этом, необходимо учитывать наличие внутрипопуляционной вариабельности растений и характера изменения амплитуды этого варьирования [4]. У сортов льна-долгунца биологическая устойчивость растений изменялась от $56,42 \%$ (2018 г.) до 84,59 \% (2019 г.); у льна масличного - от 45,34 \% (2018 г.) до 79,48 \% (2017 г.). Высокие значения признака в среднем за 2017-2019 гг. установлены у сортов долгунцового типа (Ярок, 80,51 \%; Дукат 80,44 \%; Alizee, 77,31 \%; Импульс, 75,32 \%, Томич, 70,22 \%; Маяк, 69,39\%; Томский$16,67,33 \%$; Прибой, 66,00 \%; Ikar 332, 66,03 \%); масличного (Северный, $80,41 \%$; McGregor, 77,51 \%; Кустанайский янтарь, 70,38 \%; Исилькульский, 69,52 \%; Бирюза, 68,01 \%; Mikael, 67,41 \%).

Согласно S.A. Eberhart, W.W. Russell, экологическая стабильность определяется $\left(\mathrm{S}^{2} \mathrm{~d}_{\mathrm{i}}\right)$, пластичность $\left(\mathrm{b}_{\mathrm{i}}\right)$. Исследования по льну, с использованием данного метода не многочисленны $[5,6]$. Нами установлена неоднозначность ответных реакции сортов льна на изменение факторов среды. Выделены следующие группы сортов: нестабильные $\left(\mathrm{b}_{\mathrm{i}}<1, \mathrm{~S}^{2} \mathrm{~d}_{\mathrm{i}}=0\right)$; стабильные $\left(\mathrm{b}_{\mathrm{i}}=1, \mathrm{~S}^{2} \mathrm{~d}_{\mathrm{i}}=0\right)$; нестабильные с высокой отзывчивостью в благоприятных 
условиях среды $\left(\mathrm{b}_{\mathrm{i}}>1, \mathrm{~S}^{2} \mathrm{~d}_{\mathrm{i}}=0\right)$.

Таким образом на основе полевого изучении сортов льна - долгунца и льна масличного выявлен адаптивный потенциал сортов по количественным показателям. В результате оценки выявлены источники полевой всхожести семян, биологической устойчивости растений и высоты растения для условий юга Тюменской области.

\section{Список литературь}

1. Методические указания по селекции льна-долгунца / Л.Н. Павлова [и др.]; Всерос. науч.- исслед. ин-т льна. - Торжок [б. и.], 2004.- 44 с.

2. Eberhart, S.A. Stability parameters for comparing varieties / S.A. Eberhart, W.W Russell // Crop Science. - 1966. - Vol. 6, № 1. - P. 36-40.

3. Доспехов, Б.А. Методика полевого опыта (с основами статистической обработки результатов исследований) / Б. А. Доспехов. - Изд. 3-е, перераб. и доп. - М.: Колос, $1972 .-399$ с.

4. Методы определения устойчивости растений: курс лекций / сост. Ю.П. Федулов - Краснодар: КубГАУ, 2015. - 39 с.

5. Полонецкая, Л.М. Идентификация при отборе генотипов льна-долгунца (Linum usitatissimum L.) в различных условиях выращивания / Л.М. Полонецкая, В.3. Богдан, И.А. Голуб // Вес. Нац. акад. Беларусі. Сер. біял. навук. - 2009. - № 2.- С. $22-27$.

6. Королев, К.П. Экологический скрининг коллекционных образцов льна-долгунца в условиях северо-востока Беларуси/ К.П. Королев // «Молодежь в науке»: материалы Межд. молод.- конф., Минск, 18-19 ноября 2014 г. / Нац. акад. наук Беларуси; редкол.: В.В. Казбанов [и др.]. - Минск, 2014. - С. 24.

DOI 10.18699/GPB2020-40

\section{Мировые генетические ресурсы риса и отечественные достижения в селекции на качество зерна}

Коротенко Т.Л. ${ }^{1 *}$, к.с.-х.н., руководитель группь УНУ, с.н.с.; Садовская Л.Л. ${ }^{2}$, зав. справочно-библиографическим отделом, м.н.с.

${ }^{1}$ ФГБНУ ФНЦ риса, г. Краснодар, Россия;

${ }^{2}$ ГПНТБ СО РАН, г. Новосибирск, Россия.

*e-mail: korotenko.tatyan@mail.ru

В статье обобщены данные по изучению в 2014-2019 г2. генетических ресурсов риса отечественной и зарубежной селекции из коллекции ФНЦ риса, которая насчитывает более 7 тыс. образиов из 42 стран мира. Приведены показатели качества зерна традиционных кубанских сортов и достижений ведущих рисосеющих стран, выращенных в Краснодарском крае. Ведется селекиия эксклюзивных сортов на широкий потребительский cпрос.

Ключевые слова: рис, семенная коллекиия, сорт, селекиия, качество зерна. 